\title{
Student-Teacher Perception of Time Allocation and Academic Achievement in Tai Solarin University of Education
}

\author{
Mushay A. Ogundipe and Olufemi A. Falade \\ Department of Educational Management, \\ Tai Solarin University of Education, \\ Ijagun, Ijebu-Ode, Nigeria. \\ Email: mushayogundipe@yahoo.com
}

Doi:10.5296/ijld.v4i1.5132 URL: http://dx.doi.org/10.5296/ijld.v4i1.5132

\begin{abstract}
This paper focuses on the perception of the students of Tai Solarin University of Education on the effect of time allocation and their academic achievement. This paper investigates the effect the students think time allocation such as attending lectures regularly, allocating time for self-study and participation in work group/tutorial would have on their academic achievement. The findings suggest that most students agree that time spent attending lectures, self-study and work group/tutorials is positively correlated with their academic achievement.
\end{abstract}

Keywords: Time Allocation, Academic Achievement, Students.

\section{Introduction:}

Time is an aspect of nature on which no one has absolute control. Therefore, it has become highly expedient for everyone to make fruitful use of the little time at his/her disposal in the execution of a specific task on hand. Everyday of life witnesses varied tasks being initiated and executed by various kinds of people, be it individuals, corporate bodies and or governments. The effective and efficient use of time in executing a set task will usually go a long way in determining the level of achievements and successes of objectives that are set as targets.

For students attending various course of disciplines in universities, time allocation to their day-to-day activities, particularly their academic field of study, has become almost a mirage. It is therefore not unusual to find students who shift the blame of their ineptitude on lack of enough time after failing to use the available time judiciously. Drucker (1994) is of the opinion that we must know where our time goes first and make sure we have prioritized objectives for our works and make sure we carve out sufficient time for them in order of their importance.

There is no denying the fact that time is scarce. It is however regrettably the only commodity that most students in higher institutions think is in abundance, as they engage in idle talks and unprofitable activities to the detriment of their academic pursuits. There are many indicators of students' failure to allocate sufficient time to their academic activities. Some of these are inability to submit assignment and projects on schedule, outright failures, cheating to pass tests and examinations and comparatively low level of academic achievement. 
Similarly, postulating on the issue of time and its effective allocation to daily activities, Blair (2005) as quoted by Ashiru and Arogundade (2008) writes that effective time management is synonymous with the application of the three "Es" of time management, that is, Effective, Efficient and Effortless usage of time. By effective, Blair (2005) opines that time should be seen as having a definite or desired effect while efficient means time should be productive with minimum waste or effort while effortless use of time could print tasks or set goals being achieved without effort or achieved naturally and in an easy manner.

Achieving academic excellence has become almost impossible, an uphill task that students in higher institutions now deem surmountable by only those who are academically gifted among them, a factor that many of them never attributed to the differences in time they have allocated to attending lectures, doing exercises and practical in the laboratories, reading for more facts and information from available textbooks in the library and the number of hours they have allotted to further reading on their own or with others during tutorials. Effective and efficient time allocation to various academic activities is the basic reasons some students excelled.

While Akinmayowa is doing the right job, knowing what to do and when to do it. That is investing one's time for the greatest return; Scott (1980) believes that efficiency is doing the right job in the right way. Any student who achieves academic excellence having to wait till the last minute to read and prepare under tension for examinations could be said to be effective if the results of the examinations would take such a student out of the failure zone whereas an efficient student is that who has made effortless usage of his/her time in executing his/her academic tasks such that when examinations approach, they become natural and hence are passed easily and well too, an advantage over late starters.

\section{Research Problem and Hypotheses:}

Efficient time-allocation to academic activities should be the drive of students in higher institutions which would ultimately save them from the embarrassing phenomenon of having to cheat to pass or record poor grades. How time is allocated to academic activities by students in higher institutions could be a function of students' special interest in the course of study they are pursuing, and this could make them allocate sufficient time as achievement in that course would translate to fulfillment of their larger goal in life while those who are not prepared for the course of study would find it difficult understanding what is being taught in the course and they tend to push aside further studies in the course until examination period.

Also, economic considerations have also impacted on the quality of time that is allocated to academic activities by the students. Many students combined work and study in order to satisfy the constraints of financial demand that the course could exert on them.

However, no matter what other activities students may engage in, it is important that they prioritize the need to achieve academic excellence, and such achievement is a relation of time allocated. In an effort to establish how student time allocation would impact on their academic achievement the following hypotheses are postulated:

$\mathrm{HO}_{1}$ : Student's attendance at lecture does not significantly affect academic achievement.

$\mathrm{HO}_{2}$ : Students' engagement in extra-study after normal classes does not significantly affect academic achievement.

$\mathrm{HO}_{3}$ : Students' attendance at work group/tutorial classes does not significantly affect academic achievement.

\section{Review of Literature:}

There have been several studies done to investigate the effect of students' time allocation on academic achievement. Most of these studies are however focused on student time allocation and its effects on student performance using varying degrees of variables to determine the significance of time allocation to academic achievement. 
Barbara, Grace (2010) in her paper investigates the effect of student's time allocation on the average grade of undergraduate students by focusing on gender, ability and field of study as considerable factors. The results of the study conclude that time spent by students in attending courses is positively associated with grades for females, high ability students and students of social sciences/Engineering. The study also discovers that student who spent time on self study and other study-related activities such as working as a student assistant or tutor is positively correlated with grades acquired while devoting time for attending tutorials or student work-groups is discover to have negative effect on student grades particularly on students in Sciences/Engineering whose ability is below average.

Becker (1965) on his part raised the problem of individuals' time allocation based upon the assumption that households are both consumers and producer of time. In respect to students, Becker (2005) concludes that time allocation problem can be seen as the problem of maximizing the output (measured in grades) by choosing the optimal input of time for different (correcting) activities.

However, Levin and Tsang (1987) differ in approach to the effects time-allocation would have on student performance. They approach the subject by developing a theoretical model of the student time allocation problem using an educational production function that is expended by variables representing student effort and time. The study assumed that the student has at his/her disposal the resources of both time and effort. These resources, they believe, a student could combine to produce activities efficiently in order to maximize their utility.

Many other scholars (Schmidt, 1983; Park and Kerr, 1980 Romer, 1993, etc) in their various studies on student time allocation and academic achievement are of the beliefs that attendance at lectures positively affects academic performance of students. In the same vein, Ryan, Delaney and Harmon (2010), using separate regressions for types of time use (lecture attendance and self-study), they find that non-cognitive abilities such as future-orientation and conscientiousness are important for the amount of time students spent on both attending lectures and self-study.

Implicitly, Ryan, Delaney and Harmon (2010) do not limit student performance to variables such as ability, gender and field of study as they are of the opinion that other factors such as determination to succeed and representative of the future larger goal of student in the course they are doing could influence the amount of time allocated to such courses thereby leading to academic achievement irrespective of such students cognitive ability.

\section{Methodology:}

The design of this study is a survey in which primary data were gathered with the use of a questionnaire. The analyses and findings in this study were mainly based on information derived from the responses elicited through the questionnaires involving one hundred and twenty (120) respondents drawn from the total population of final year students of 2,155 of the four Colleges of Tai Solarin University of Education.

A simple random sampling technique was used to select thirty (30) students from final year students of each College of the University. A self-designed questionnaire tagged "Effect of Student Time Allocation and Academic Achievement (ESTAAA)" was the main instrument for the study. The questionnaire generally consisted of two sections structured to obtain focused information on the objectives of the research. Section A sought demographic information of the respondents such as sex, marital status, age and College of study of the respondents. Section B of the questionnaire contained ten (10) structural items of four (4) scales Likert Model refined statements where the respondents indicated their level of agreement or otherwise to the research statements relating to students time allocation and academic achievement.

All responses were subjected to inferential statistics of t-test analysis and were tested at $\mathrm{p}<0.05$ level of significance. 


\section{Data Analysis and Results:}

$\mathrm{HO}_{1}$ : Students' attendance at lecture does not significantly affect academic achievement.

Table 1: Summary of t-test analysis of students' attendance at lectures and academic achievement.

\begin{tabular}{|l|c|c|c|c|c|c|c|}
\hline Subject & Mean X & SD & No & df & $\begin{array}{c}\mathrm{t} \\
\text { calculated }\end{array}$ & t critical & $\begin{array}{c}\text { Level of } \\
\text { Significance }\end{array}$ \\
\cline { 1 - 4 } Agree & 3.28 & 0.05 & 104 & & & & \\
\cline { 1 - 6 } Disagree & 2.94 & 0.21 & 16 & 118 & 22.72 & 1.62 & 0.05 \\
\hline
\end{tabular}

$\mathrm{N}=120$

Since t- calculated is greater than the critical value (i.e. $22.72>1.65$ ), it therefore implies that the null hypothesis $\mathrm{H}_{1}$ (which states that students' attendance at lectures does not significantly affect academic achievement) is rejected. It therefore implies that students' regular attendance at lecture influences academic achievement.

$\mathrm{HO}_{2}$ : Students' engagement in extra-study after normal classes does not significantly affect academic achievement.

Table 2: Summary of t-test analysis students' engagement in extra-study after normal classes and students' academic achievement.

\begin{tabular}{|l|c|c|c|c|c|c|c|}
\hline Subject & Mean X & SD & No & df & $\begin{array}{c}\mathrm{t} \\
\text { calculated }\end{array}$ & t critical & $\begin{array}{c}\text { Level of } \\
\text { Significance }\end{array}$ \\
\cline { 1 - 4 } Agree & 3.03 & 0.49 & 96 & & & & \\
\cline { 1 - 5 } Disagree & 2.47 & 0.44 & 23 & 118 & 14.69 & 1.65 & 0.05 \\
\hline
\end{tabular}

$\mathrm{N}=120$

Since t-calculated is greater than the critical value (i.e. $14.69>1.65$ ), it therefore implies that the null hypothesis $\mathrm{HO}_{2}$ (which states that students' engagement in extra-study after normal classes does not significantly affect students' academic achievement) is rejected. This therefore implies that students' engagement in extra-study after normal classes influences their academic achievement.

$\mathrm{HO}_{3}$ : Students' attendance at work group/tutorial classes does not significantly affect academic achievement.

Table 3: Summary of t-test analysis students' attendance at work group/tutorial classes and student academic achievement.

\begin{tabular}{|l|c|c|c|c|c|c|c|}
\hline Subject & Mean X & SD & No & df & $\begin{array}{c}\mathrm{t} \\
\text { calculated }\end{array}$ & t critical & $\begin{array}{c}\text { Level of } \\
\text { Significance }\end{array}$ \\
\hline Agree & 3.22 & 0.42 & 89 & \multirow{2}{*}{118} & 23.63 & 1.65 & 0.05 \\
\hline Disagree & 2.70 & 0.31 & 31 & 18 & \\
\hline
\end{tabular}

$\mathrm{N}=120$.

Since t-calculated is greater than the table/critical value (i.e. $23.63>1.65$ ), it therefore implies that the null hypothesis $\mathrm{HO}_{3}$ (students' attendance at work group/tutorial classes does not significantly affect academic achievement) is rejected. It therefore implies that students' attendance at work group/tutorial classes significantly influences students' academic achievement.

\section{Discussion:}

The purpose of this study is to find out the effect students' time allocation would have on their academic achievement. From the investigation in this study, it is evident that there is a relationship between time allocated to academic activities and academic achievement of students. 
The findings in Table 1 of this study regarding the significance of regular attendance at lecture and academic achievement confirmed the earlier position of Schmidt (1983); Park and Kerr (1990); Romer (1993); Bauer and Zimmermann (1998) that attendance at lectures definitely has positive effect on academic performance of students. Similarly, Stinebrickner and Stinebrickner (2008) while investigating the causal effect of spending time for studying on academic achievement concluded that there is evidence that an increase in study quantity by one hour increases student performance significantly.

Furthermore, Table 2 of this study concludes that engagement in extra-study after normal classes by students would significantly influence their academic achievement. This finding is contrary to the conclusion of Dolton, Mercenario and Navarro (2003) that time spent on lectures is more productive than time spent on self on self-study as they believe that time used for private tuition has a negative effect based on their findings from first and final year students at the University of Malaga (Spain). However, Bralti and Staffolani (2002) investigation of the effect of self-study on academic achievement, using first and final year economic students of the University of Ancona (Italy) find that while attendance at lectures seems to improve performance especially in quantitative discipline such as Mathematics and Economics, self-study seems to be more important for non-quantitative disciplines such as Law and Economic History.

The investigation of the effect of attendance at work group/tutorial would have on academic achievement as shown on Table 3 of this study establishes a positive connection between students' academic achievement and attendance at work group/tutorial. Contrarily, Barbara (2010) in her study is of the opinion that time devoted to student work group or tutorial appears to be negatively associated with academic achievement especially for students with low ability and those of Sciences/Engineering.

\section{Recommendations:}

Since the objectives of this study are to examine the effect of student time allocation on academic achievement, it would be appropriate to recommend to students and scholarly-minded people to devote time in quality and quantity to their academic activities to ensure optimal output. As Meng and Heijke (2005) write that attending courses solely increases the efficiency of acquiring discipline-specific competences whereas it is harmful for generic competences. They however conclude that self-study and subject-related work increase both type of competences. What this means is that engagement in self-study after classroom teaching would widen the scope of knowledge of its practitioners beyond what is generally taught during lectures.

\section{Conclusion:}

There is no doubt that quality time allocation to academic activities is vital and imperative to sterling achievement in scholastic pursuits. Students in tertiary institutions, like TASUED, should endeavour to observe whatever negative challenges they might have in allocating sufficient time to lecture attendance, self-study and work group/tutorial and strive to remove such impediments to their academic progress.

It must be noted that the investigation made here is constrained by the fact that subjective opinion of students were used to explain the relation between the students' use of time and their academic achievement. This may not be enough to make valid conclusions. There is the need to measure, in empirical terms, the time allocation and the actual performance of students to know the magnitude of the effect of time use on achievement.

\section{References:}

Akinmayowa, J.T. (1995). "Management and leadership today and tomorrow-

Peter Drucker's Perspective" In Nigerian Mamagement Review Vol.9 (2) and Vol.10 (1). Lagos: Centre for Management Development (CMD). 
Barbara, S.G. (2010). "The effect of time allocation on academic achievement". In

Schmidt, C.M. (ed) Ruhr economic papers. Germany: Ruhr-Universitat Bochum (RUB), Department of Economics.

Bauer, T. and Zimmermann, K.F. (1998). "Learning efficiency of economic students," IZA Discussion Papers No.23, Institutte for the Study of Labour (IZA).

Becker, G.S. (1965). "A theory of the allocation of time," The Economic Journal, 75 (299), 493-517s.

Blair, M.G. (2005). "Personal time management for busy managers", in The basics of personal time management. United Kingdom: Chartwell-Bratt Publishers.

Bralti, M. and Staffolani, S. (2002). "Student time allocation and educational production functions," Quaderns di Ricerca n.170.

Dolton, P., Mercenaro, O.D., and Navarro, L. (2003). "The effective use of student time: a stochastic frontier production function case study" Economics of Education Review, 22, $547-560$.

Drucker, P.F. (1994). The Effective Executive. New York: Harper and Row.

Levan, H.M., and Tsang, M.C. (1987). "The economics of student time," Economics of Education Review, 6(4), 357-364.

Meng, C. and Heijke, H. (2005). "Student time allocation, the learning environment and the acquisition of competencies," Research Memoranda 001. Maastricht: ROA Research Centre for Education and the Labour Market.

Park, K.H. and Kerr, P.M. (1990). "Determination of academic performance: a multinominal logit approach," Journal of Economic Education, 21(2), 101-111.

Ryan, M. Delaney, I. and Harman, C.P. (2010). "Micro-level determinants of lecture attendance and additional study hours." IZA Discussion Papers 5144, Institute for the Study of Labour (IZA).

Romer, D. (1993). "Do students go to class? Should they?" The Journal of Economic Perspectives, 7(3), 167-174.

Schmidt, R.M. (1983). "Who maximizes what? A study in student time allocation," The American Economic Review, 73(2), 23-28

Stinebrickner, R. and Stinebricker, T.R. (2008). "The causal effect of studying on academic performance," The B.E. Journal of Economic Analysis \& Policy, 8(1) Frontiers, Article 14.

Winston, S. (1983). The organized executive: new ways to manage time, paper and people. New York: W.W. Norton and Co. 